\title{
PENGARUH PENDAPATAN, GAYA HIDUP, DAN JENIS KELAMIN TERHADAP KONSUMSI MAHASISWA JURUSAN PENDIDIKAN MATEMATIKA UIN ALAUDDIN MAKASSAR
}

\author{
Nur Yuliani \\ Email : nur.yuliany@uin-alauddin.ac.id \\ Fakultas Tarbiyah dan Keguruan UIN Alauddin Makassar \\ Jl. Yasin Limpo Samata-Gowa \\ Rahmatiah \\ Email : rahmatiayunus@gmail.com \\ Fakultas Ekonomi dan Bisnis Universitas Hasanuddin Makassar \\ Jl. Perintis Kemerdekaan
}

\begin{abstract}
ABSTRAK
Pendapatan atau uang saku yang dimiliki mahasiswa bisa berasal dari orang tua/saudara, dari beasiswa, ataupun dari bekerja. Sebagian dari mahasiswa seringkali menghabiskan pendapatan atau uang saku yang dimiliki untuk konsumsi sementara tidak ada bagian pendapatan yang ditabung. Tujuan dari penelitian ini yaitu ingin mengetahui pengaruh pendapatan, gaya hidup, dan jenis kelamin terhadap tingkat konsumsi mahasiswa Jurusan Pendidikan Matematika. Populasi penelitian ini, mahasiswa Jurusan Pendidikan Matematika angkatan 2017-2019. Teknik pengambilan sampel Proportionate Stratified Random Sampling. Pengujian hipotesis dilakukan dengan analisis regresi linier berganda. Hasil penelitian menunjukkan: (1) Pendapatan berpengaruh positif dan signifikan terhadap tingkat konsumsi mahasiswa, ditunjukkan dengan nilai koefisien pendapatan bertanda positif yaitu sebesar 0,585 (2) Gaya hidup berpengaruh positif dan signifikan terhadap tingkat konsumsi mahasiswa, ditunjukkan dengan nilai koefisien gaya hidup bertanda positif yaitu sebesar 1173,744 (3) Jenis kelamin berpengaruh signifikan terhadap tingkat konsumsi mahasiswa, ditunjukkan dengan nilai koefisien jenis kelamin bertanda negatif yaitu sebesar -204005 (4) Pendapatan, gaya hidup, dan jenis kelamin secara bersama-sama berpengaruh signifikan terhadap tingkat konsumsi mahasiswa. Dan diperoleh nilai koefisien determinasi (R2) sebesar 0,832 atau 83,2\%. Nilai tersebut menunjukkan bahwa 83,2\% tingkat konsumsi dipengaruhi oleh pendapatan, gaya hidup, dan jenis kelamin, sedangkan sisanya $16,8 \%$ dipengaruhi oleh variabel bebas lain yang tidak diteliti.
\end{abstract}

Kata Kunci: Tingkat Konsumsi, Pendapatan, Gaya Hidup, Jenis Kelamin

\section{ABSTRACT}

Income or pocket money owned by students can come from parents / relatives, from scholarships, or from work. Some students often spend their income or pocket money for consumption while there is no part of the income saved. The purpose of this study is to find out the influence of income, lifestyle, and gender on the level of consumption of students of the Department of Mathematics Education. The population of this study is the students of the Department of Mathematics Education class of 20172019. The Proportionate Stratified Random Sampling technique. Hypothesis testing is done by multiple linear regression analysis. The results showed: (1) Income had a positive and significant effect on the level of consumption of students, indicated by the coefficient of income positive sign that is equal to 0.585 (2) Lifestyle has a positive and significant effect on the level of student consumption, indicated by the value of the lifestyle coefficient that is positive 1173,744 (3) Gender significantly influences the level of student consumption, indicated by the coefficient value of the negative gender that is equal to 204005 (4) Income, lifestyle, and gender together have a significant effect on the level of student consumption. And the obtained coefficient of determination (R2) of 0.832 or $83.2 \%$. This value indicates that $83.2 \%$ of the level of consumption is influenced by income, lifestyle, and gender, while the remaining $16.8 \%$ is influenced by other independent variables which is not examined.

Keywords: Consumption Rate, Income, Lifestyle, Gender 


\section{PENDAHULUAN}

Peringkat kedua diduduki Indonesia sebagai negara terkonsumtif di dunia sebagaimana penelitian yang dilakukan oleh AC Nielsen (Safira, 2012). "Warga Indonesia dikatakan lebih bersifat konsumtif, dibuktikan pada masa sekarang, Indonesia menduduki peringkat kedua penyandang untuk negara paling konsumtif didunia". Seperti yang diungkapkan Happy Tranggono, Ketua Indonesian Islamic Business Forum (IIBF) ini mengatakan bahwa pada saat sosialisasi Gerakan Beli Indonesia dan rencana Kongres Kebangkitan Ekonomi Indonesia di Hotel Riyadi Palace (Tarapti, 2013). Dikatakan bahwasanya prilaku konsumtif yang hinggap pada masyarakat terjadi pula di kalangan mahasiswa, hal ini juga terjadi pada mahasiswa Jurusan Pendidikan Matematika. "Surindo melakukan survei dan menemukan bahwa kalangan remaja di Indonesia saat ini semakin konsumtif, senang ganta-ganti merk, mudah terayu kemajuan trend, dan suka berpenampilan keren" (Sonia, 2008). Seperti yang diungkapkan oleh Hill dan Monks bahwasanya remaja merupakan individu yang berumur antara 12 tahun sampai 24 tahun (Anin, 2008). Dalam hal ini, mahasiswa yang berada pada usia rentang ini maka mereka digolongkan sebagai remaja.

Pada keseluruhan ekonomi, tingkat konsumsi pada unit terkecil ditentukan oleh pendapatan rumah tangga (Sukirno, 2013). Reksoprayitno mendefinisikan total penerimaan yang diperoleh pada periode tertentu merupakan pendapatan (Danil, 2013). Pendapatan individu merupakan macam-macam jenis pendapatan, salah satunya pendapatan yang diperoleh dengan tidak melakukan suatu kegiatan apa pun. Jika pendapatan individu dikurangi pajak yang wajib dibayar oleh yang menerima pendapatan, harga yang tersisa disebut sebagai pendapatan disposibel (Sukirno, 2013).

"Pola dimana orang hidup dan menghabiskan waktu serta uang disebut sebagai gaya hidup" (Engel, James F, 1994). Seiring kemajuan zaman, gaya hidup masyarakat pun bervariasi dan berubah. Gaya hidup masyarakat cenderung modern, sebagian besar orang sangat sering membeli barang di tempat perbelanjaan yang modern daripada di tempat tradisional seperti pasar. Seperti diketahui, di Makassar telah banyak terbuka pusat pembelanjaan seperti mall, swalayan, minimarket, pertokoan, distro, dan sebagainya sehingga orang berkeinginan untuk berbelanja (shopping). Orang-orang melihat berbagai hal yang sedang trend, seperti halnya yang terjadi pada kalangan mahasiswa. Kebanyak dari mahasiswa mengikuti perkembangan mode yang sekarang banyak diminati, seperti pakaian, sepatu, tas, dan aksesoris. Di bidang teknologi, perkembangan gadget sangatlah 
berkembang dengan pesat. Produk baru yang dikeluarkan di masyarakat seperti smartphone, kamera, sampai aksesoris gadget begitu besar daya tarik yang dikeluarkan pada mahasiswa. Ada mahasiswa yang melakukan konsumsi tersebut agar tidak merasa ketinggalan zaman. Jadi gaya hidup mahasiswa kita cenderung konsumtif.

Kefgen dan Sprech dalam (Sonia, 2008), mengatakan bahwasanya remaja putri mengeluarkan uang lebih besar dari remaja putra. Remaja putri tidak mau diberi cap sebagai remaja yang kuno, baik dalam hal berbusana, gaya rambut, berdandan, maupun dalam hal lainnya. Sedangkan menurut Reynold dan Wells dalam (Resi Karoma, 2013), dilihat dari jenis kelamin biasanya wanita lebih konsumtif dibandingkan dengan para pria. Hal ini disebabkan wanita lebih banyak mengeluarkan uangnya daripada pria untuk keperluan penampilan seperti pakaian, kosmetik, aksesoris, dan sepatu. Wanita merupakan konsumen potensial untuk produk-produk seperti pakaian, kosmetik, aksesoris, dan sepatu. Wanita lebih mudah terbujuk iklan, suka ikut-ikutan teman, serta cenderung boros dalam menggunakan uangnya untuk keperluan rekreasi dan hobi.

Konsumsi merupakan pembelanjaan barang dan jasa oleh rumah tangga (N. Gregory, 2012). Pengeluaran untuk konsumsi seseorang adalah bagian dari pendapatan yang diperolehnya kemudian dibelanjakan. Sementara bagian pendapatan yang tidak dipergunakan untuk belanja dinamakan sebagai tabungan (Dumairy, 1999). Konumsi setiapa individu dalam malakukan belanja pengeluaran berbeda-beda. Besarnya belanja untuk pengeluaran konsumsi ini bervariasi, dimana antara individu yang satu dengan yang lainnya berbeda tingkat konsumsinya. Ada beberapa faktor yang dapat mempengaruhi tingkat belanja konsumsi seseorang, dalam hal ini yang dimaksudkan adalah tingkat konsumsi mahasiswa. Faktor yang diduga mempengaruhi belanja konsumsi mahasiswa antara lain yaitu faktor pendapatan, gaya hidup, dan juga jenis kelamin. Pendapatan atau uang saku yang dimiliki mahasiswa bias saja berasal dari orang tua atau saudara, dari beasiswa, ataupun dari bekerja. Sebagian besar mahasiswa cenderung untuk menghabiskan pendapatan atau uang saku yang dimiliki untuk belanja konsumsi sementara tidak ada bagian dari pendapatan yang ditabungnya.

Menurut (Sudibyo, 2008), hasil penelitiannya menunjukkan bahwa variabel yang berpengaruh terhadap tingkat konsumsi suplemen vitamin $\mathrm{C}$ adalah angkatan, penyakit menetap yang diderita, kebiasaan olah raga, dan status kesehatan. Perbedaan dalam penelitian ini yaitu tingkat konsumsi yang dimaksudkan adalah tingkat konsumsi suplemen 
vitamin $\mathrm{C}$, perbedaannya ada pada variabel independen yang digunakan. Persamaan dalam penelitian ini yaitu sama-sama meneliti tingkat konsumsi.

Adapun tujuan dalam penelitian yang dilakukan adalah (1). Untuk mengetahui pengaruh pendapatan terhadap tingkat konsumsi mahasiswa Jurusan Pendidikan Matematika. (2). Untuk mengetahui pengaruh gaya hidup terhadap tingkat konsumsi mahasiswa Jurusan Pendidikan Matematika. (3). Untuk mengetahui pengaruh jenis kelamin terhadap tingkat konsumsi mahasiswa Jurusan Pendidikan Matematika. (4). Untuk mengetahui pengaruh pendapatan, gaya hidup, dan jenis kelamin terhadap tingkat konsumsi mahasiswa Jurusan Pendidikan Matematika Karena lebih mudah dilakukan penelitian sebab saya mengajar di Jurusan Pendidikan Matematika.

\section{METODE PENELITIAN}

Penelitian yang dilakukan termasuk jenis penelitian ex-post facto dan asosiatif kausal. Populasi dalam penelitian ini yaitu mahasiswa Jurusan Pendidikan Matematika angkatan 2017-2019, yang berjumlah 233 orang mahasiswa, dimana mahasiswa angkatan 2017 sebanyak 79 orang, mahasiswa angkatan 2018 sebanyak 72 orang, dan mahasiswa angkatan 2019 sebanyak 82 orang. Dengan menggunakan Teknik pengambilan sampel Proportionate Stratified Sampling, dimana sampel yang diambil sebanyak 70 orang mahasiswa. Teknik pengumpulan data yaitu menggunakan kuesioner dan dokumentasi, dimana instrumen penelitian berupa kuesioner beserta indikatornya. Sedangkan teknik analisis data yang digunakan adalah analisis statistik deskriptif serta analisis statistik inferensial. Pengujian hipotesis dilakukan dengan analisis regresi linier berganda, dipergunakan aplikasi SPSS 24.

\section{HASIL DAN PEMBAHASAN}

Data hasil penelitian yang dilakukan diperoleh melalui kuesioner yang berisi pertanyaan atau pernyataan tertulis yang diberikan kepada responden. Data penelitian mencakup data variabel terikat yaitu tingkat konsumsi mahasiswa Jurusan Pendidikan Matematika UIN Alauddin Makassar. Sedangkan data variabel bebas meliputi variabel pendapatan, gaya hidup, dan jenis kelamin. Untuk mendeskripsikan dan menguji pengaruh variabel bebas terhadap variabel terikat digunakan sampel sebanyak 70 respoden yang terdiri dari mahasiswa Jurusan Pendidikan Matematika Angkatan 2017-2019. Selain data variabel penelitian, maka diperoleh juga informasi mengenai karakterisitik responden. 
Untuk lebih jelasnya, akan disajikan deskripsi data secara lebih rinci yaitu sebagai berikut:

Tabel 1. Banyaknya Responden Berdasarkan Angkatan

\begin{tabular}{ccc}
\hline Angkatan & Mahasiswa & Persentase \\
\hline 2017 & 40 & 57,14 \\
2018 & 20 & 28,57 \\
2019 & 10 & 14,29 \\
\hline Total & 70 & 100 \\
\hline
\end{tabular}

Tabel 2. Responden Berdasarkan jenis Kelamin

\begin{tabular}{ccc}
\hline Jenis Kelamin & Responden & Persentase \\
\hline Laki-laki & 13 & 18,57 \\
Perempuan & 57 & 81,43 \\
\hline Total & 70 & \\
\hline
\end{tabular}

Tabel 3. Responden Berdasarkan Usia

\begin{tabular}{ccc}
\hline Usia & Responden & Persentase \\
\hline 18 & 6 & 8,57 \\
19 & 16 & 22,86 \\
20 & 25 & 35,71 \\
21 & 22 & 31,43 \\
22 & 1 & 1,43 \\
\hline Total & 70 & \\
\hline
\end{tabular}

Tabel 4. Responden Berdasarkan Tempat Tinggal

\begin{tabular}{ccc}
\hline Tempat Tinggal & Responden & Persentase \\
\hline Kos & 41 & 58,57 \\
Tidak Kos & 29 & 41,43 \\
\hline Total & 70 & \\
\hline
\end{tabular}

Hasil dari aplikasi SPSS memperlihatkan bahwa nilai mean untuk variabel pendapatan sebesar 866190, untuk variabel gaya hidup sebesar 37,54, untuk variabel jenis kelamin sebesar 0,81 dan untuk variabel tingkat konsumsi sebesar 747364,3. Sedangkan nilai standar deviasi untuk variabel pendapatan sebesar 606559,2, untuk variabel gaya hidup sebesar 9,543, untuk variabel jenis kelamin sebesar 0,392 dan untuk variabel tingkat konsumsi sebesar 428231,7.

Tabel 5. Hasil SPSS untuk Mean dan Standar Deviasi

\begin{tabular}{lcccc}
\hline & Pendapatan & Gaya Hidup & Jenis Kelamin & Tingkat Konsumsi \\
\hline Mean & 866190 & 37,54 & 0,81 & 747364,3 \\
\hline Standar deviasi & 606559,2 & 9,543 & 0,392 & 428231,7 \\
\hline
\end{tabular}


Dari hasil analisis regresi yang diperoleh maka persamaan regresi linier berganda dalam penelitian ini dapat diformulasikan sebagai berikut:

$$
\mathrm{Y}=362429,8+0,585 \mathrm{X} 1+1173,744 \mathrm{X} 2-204005 \mathrm{D} 1
$$

Persamaan regresi linier berganda tersebut dapat dijelaskan sebagai berikut:

1. Bilangan konstanta bertanda positif yaitu sebesar 362429,8 artinya apabila variabel pendapatan (X1), gaya hidup (X2) dianggap konstan, dan tidak mempermasalahkan jenis kelamin (D1) responden, maka tingkat konsumsi (Y) akan sebesar Rp362429,8

2. Koefisien pendapatan bertanda positif yaitu sebesar 0,585 artinya setiap perubahan variabel pendapatan (X1) sebesar Rp10.000,00 maka akan meningkatkan tingkat konsumsi (Y) sebesar Rp5.850,00. Dengan asumsi variabel gaya hidup (X2) dianggap konstan, dan tidak mempermasalahkan jenis kelamin (D1) responden.

3. Koefisien gaya hidup bertanda positif, artinya ketika mahasiswa mempunyai gaya hidup (X2) cenderung semakin konsumtif maka akan meningkatkan tingkat konsumsinya (Y). Dengan asumsi variabel pendapatan (X1) dianggap konstan, dan tidak mempermasalahkan jenis kelamin (D1) responden.

4. Koefisien jenis kelamin bertanda negatif yaitu sebesar -204005 menunjukkan bahwa mahasiswa perempuan ( $\mathrm{D}=1)$ mempunyai tingkat konsumsi (Y) lebih rendah dibandingkan mahasiswa laki-laki $(\mathrm{D}=0)$.

Selanjutnya pembahasan dari hasil yang diperoleh adalah sebagai berikut :

1. Pendapatan

Pendapatan mempunyai pengaruh positif dan signifikan terhadap tingkat konsumsi mahasiswa Jurusan Pendidikan Matematika. Sehingga semakin tinggi pendapatan mahasiswa maka akan semakin tinggi pula tingkat konsumsi mahasiswa tersebut. Begitu pula sebaliknya, jika pendapatan mahasiswa rendah maka tingkat konsumsinya juga akan rendah pula.

Hasil yang diperoleh, sejalan dengan yang dikatakan oleh (Sukirno, 2013) bahwa pendapatan rumah tangga menentukan tingkat konsumsi dengan unit terkecil atau dalam keseluruhan ekonomi. Hasil yang diperoleh juga sejalan dengan yang dikatakan Godam dalam (Sutanti, 2011), bahwa semakin tinggi pendapatan, pada umumnya pengeluaran konsumsi akan mengalami peningkatan.

Hasil yang diperoleh juga sesuai dengan penelitian sebelumnya yang dilakukan oleh (Rabbani, 2014), bahwa gaji dan uang saku berpengaruh positif dan signifikan terhadap 
konsumsi makanan maupun non makanan mahasiswa PTN yang bekerja di Makassar. Gaji dan uang saku tidak lain merupakan bagian dari pendapatan. Hasil yang diperoleh ini pula, sesuai dengan penelitian sebelumnya yang telah dilakukan oleh (Nasution, 2006), bahwa pendapatan berpengaruh positif dan signifikan terhadap tingkat konsumsi di Sumatera Utara.

\section{Gaya Hidup}

Hasil pyang diperoleh, gaya hidup berpengaruh positif dan signifikan terhadap tingkat konsumsi mahasiswa Jurusan Pendidikan Matematika. Gaya hidup yang dimaksud merupakan gaya hidup yang cenderung konsumtif. Sehingga ketika mahasiswa mempunyai gaya hidup cenderung semakin konsumtif, akan semakin tinggi juga tingkat konsumsi mahasiswa tersebut. Dan sebaliknya, jika gaya hidup mahasiswa cenderung semakin tidak konsumtif, tingkat konsumsi mahasiswa juga akan rendah.

Gaya hidup yang cenderung konsumtif berkaitan langsung dengan barang mewah atau pun barang dengan harga yang mahal. Hal ini telah tertuang pada soal pernyataan kuesioner penelitian ini. Godam dalam (Sutanti, 2011), menunjukkan dimana seseorang yang menyukai gaya hidup mewah, maka tinggi tingkat konsumsinya. Jadi golongan mahasiswa dengan gaya hidup yang berada pada tingkat kategori rendah memungkinkan kurang suka gaya hidup yang mewah, sehingga rendah tingkat konsumsinya.

Hasil yang diperoleh juga seiring dengan yang dikatakan (Damsar, 1997), bahwa konsumsi dipandang bukan hanya sekedar sebagai sesuatu untuk memenuhi kebutuhan yang bersifat fisik dan biologis yang dimiliki manusia, tetapi juga berkaitan dengan aspekaspek sosial budaya. Konsumsi sejalan dengan perihal selera, identitas, atau pun gaya hidup.

\section{Jenis Kelamin}

Hasil diperoleh, jenis kelamin berpengaruh signifikan terhadap tingkat konsumsi mahasiswa Jurusan Pendidikan Matematika. Terlihat bahwa nilai koefisien jenis kelamin bertanda negatif, ini mempunyai arti bahwasanya mahasiswa perempuan mempunyai tingkat konsumsi lebih rendah disbanding dengan mahasiswa laki-laki.

Hasil yang diperoleh juga sesuai dengan hipotesis yang perlihatkan yaitu "Jenis kelamin berpengaruh signifikan terhadap tingkat konsumsi mahasiswa Jurusan Pendidikan Matematika”. Tersirat bahwa tingkat konsumsi mahasiswa laki-laki lebih tinggi dibanding dengan mahasiswa perempuan, dimana terdapat beberapa kemungkinan mengapa hal ini 
demikian. Selama ini wanita identik dengan gemar berbelanja, dimungkinkan pria lebih jarang berbelanja namun sekali berbelanja mengeluarkan jumlah uang yang jauh lebih besar dibandingkan dengan wanita. Diibaratkan dalam satu bulan wanita berbelanja lima kali, sedangkan pria hanya satu kali berbelanja namun mengeluarkan jumlah uang yang jauh lebih besar.

Hasil yang diperoleh didapatkan suatu kesimpulan yaitu pendapatan, gaya hidup, dan jenis kelamin secara bersama-sama berpengaruh signifikan terhadap tingkat konsumsi mahasiswa Jurusan Pendidikan Matematika. Selain itu dari hasil perhitungan diperoleh nilai koefisien determinasi (R2) sebesar 0,832 atau 83,2\%. Nilai tersebut menunjukkan bahwa 83,2\% tingkat konsumsi dipengaruhi oleh pendapatan, gaya hidup, dan jenis kelamin. Sedangkan sisanya 16,8\% dipengaruhi oleh variabel bebas lain yang tidak diteliti. Selain ketiga variabel bebas dalam penelitian ini, diketahui bahwa ada banyak faktor lain yang dapat mempengaruhi tingkat konsumsi khususnya mahasiswa, misalnya sikap berhemat, keadaan perekonomian, perkiraan masa depan, dan ramalan akan adanya perubahan harga. Hasil yang diperoleh juga sejalan dengan penelitian sebelumnya yang dilakukan oleh (Resi Karoma, 2013), bahwa secara simultan pendapatan, IPK, beasiswa, jurusan, dan jenis kelamin berpengaruh signifikan terhadap konsumsi mahasiswa yang indekos di Kota Makassar.

\section{KESIMPULAN}

Penelitian yang dilakukan membawa suatu kesimpulan berupa : (1). Pendapatan berpengaruh positif dan signifikan terhadap tingkat konsumsi mahasiswa Jurusan Pendidikan Matematika. Berarti bahwa semakin tinggi pendapatan mahasiswa maka akan semakin tinggi pula tingkat konsumsi mahasiswa tersebut. (2). Gaya hidup berpengaruh positif dan signifikan terhadap tingkat konsumsi mahasiswa Jurusan Pendidikan Matematika. Berarti bahwa ketika mahasiswa mempunyai gaya hidup cenderung semakin konsumtif maka akan semakin tinggi pula tingkat konsumsi mahasiswa tersebut. (3). Jenis kelamin berpengaruh signifikan terhadap tingkat konsumsi mahasiswa Fakultas Jurusan Pendidikan Matematika. Berarti bahwa mahasiswa perempuan mempunyai tingkat konsumsi lebih rendah dibandingkan mahasiswa laki-laki. (4). Pendapatan, gaya hidup, dan jenis kelamin secara bersama-sama berpengaruh signifikan terhadap tingkat konsumsi mahasiswa Jurusan Pendidikan Matematika. 
Hasil yang diperoleh serta kesimpulan yang diambil, dapat diberikan saran sebagai berikut: mahasiswa harus bijaksana dalam menggunakan pendapatan yang dimiliki, mahasiswa tidak seharusnya mengkonsumsi barang ataupun jasa hanya karena menuruti gaya hidupnya yang cenderung konsumtif, diberikan khususnya pada mahasiswa laki-laki yaitu harus bisa mengatur pengeluaran konsumsinya dengan baik, perlu menambah variabel lain selain ketiga variabel bebas dalam penelitian ini.

\section{DAFTAR PUSTAKA}

Anin, A. D. (2008). Hubungan Self Monitoring dengan Impulsive Buying terhadap Produk Fashion pada remaja. Jurnal Psikologi, 35 No.2, 181-193.

Damsar. (1997). Sosiologi Ekonomi. PT. Rajagrafindo Persada.

Danil, M. (2013). Pengaruh Pendapatan terhadap tingkat Konsumsi pada Pegawai Negeri Sipil di Kantor Bupati Bireuen. Jurnal Ekonomika, Volume IV, 33-41.

Dumairy. (1999). Perekonomian Indonesia. Erlangga.

Engel, James F, D. (1994). Perilaku Konsumen (6th ed.). PT. Binarupa Aksara.

Fidan Safira, D. (2012). UpayaMeminimalisisr Pola Hidup Konsumtif melalui Cookies pada Pusat Pembelanjaan di Malang. Universitas Brawijaya.

N. Gregory, M. (2012). Pengantar Ekonomi Makro. Salemba Empat.

Nasution, E. R. (2006). Pengaruh Pendapatan dan Tingkat Suku Bunga terhadap Tingkat Konsumsi di Sumatera Utara. Universitas Sumatera Utara.

Rabbani, M. N. (2014). Pola konsumsi Mahasiswa Perguruan Tinggi yang Bekerja di Makassar. Universitas Hasanuddin Makassar.

Resi Karoma, A. (2013). Analisis Faktor-Faktor yang Mempengaruhi Pola konsumsi Mahasiswa Indekos di Kota Makassar. Universitas Hasanuddin Makassar.

Sonia. (2008). Prilaku Konsumtif pada Mahasiswa UNIKA di Tinjau dari External Locus of Control. Universitas Katolik.

Sudibyo, R. O. (2008). Faktor-Faktor yang Mempengaruhi Tingkat Konsumsi Suplemen Vitamin C di Kalangan Mahasiswa. Universitas Islam Indonesia.

Sukirno, S. (2013). Makroekonomi Teori Pengantar (Ketiga). Rajagrafindo Persada.

Sutanti. (2011). Analisis Konsumsi masyarakat privinsi Sumatera Utara. Universitas Negeri Medan.

Tarapti, G. (2013). Analisis Strategi Bersaing Bisnis Kredit Pemilikan Rumah Bank BCA. Universitas Gadjah Mada. 